\title{
Modification of Cellulose by Using Atom Transfer Radical Polymerization and Ring-Opening Polymerization
}

\author{
By Fuxiang CHANG, Kazuhiro YAMABUKI, Kenjiro ONIMURA, and Tsutomu OISHI*
}

The cellulose chloroacetate (Cell-ClAc) with a degree of substitution (DS) value of about 2.1 was synthesized through acylation reaction of microcrystalline cellulose in a homogeneous solution of dimethylacetamide/lithium chloride (DMAc/ $\mathrm{LiCl}$ ), and pyridine as the acid acceptor. Atom transfer radical polymerizations (ATRP) of 3-ethyl-3-methacryloyloxymethyloxetane (EMO) and methyl methacrylate (MMA) were carried out by using Cell-ClAc as the initiator. Furthermore, the second ATRP reactions of MMA and EMO by using the products of Cell-PEMO and Cell-PMMA as initiators were performed, respectively. It was based on the consideration of that the terminal halogens of Cell-PEMO or Cell-PMMA possess activity even after a long time period and could be used as initiator for another ATRP reaction. Different reactions including the activators generated by electron transfer (AGET) ATRP of EMO or MMA and the Ring-Opening Polymerization (ROP) of aliphatic cyclic ester (CE) ( $\varepsilon$-caprolactone (CL), or L-Lactide (LLA)) proceed in a same reaction system simultaneously by using the same initiator of Cell-ClAc or Cell-PEMO or Cell-PMMA were also carried out. For analyses of products, the measurements of FT-IR, DSC, TG-DTA, WAXD were performed, and a Polarizing Microscope (POM) was also used for crystal observation of the products. All the measurement results proved the proceeding of the reactions.

KEY WORDS: Microcrystalline Cellulose / Modification / ATRP / the Second ATRP / AGET ATRP / ROP /

Along with the increasingly rising awareness of environmental protection and of utilizing petroleum resources more rationally and economically, more and more researchers turn the study direction from petroleum to natural and renewable resources such as the developments of biodegradable plastics and green sustainable plastics. Among the natural renewable resources, cellulose is one of the most popular materials because cellulose is the most abundant natural polymer on earth and possesses many potential outstanding properties and attractive advantages for applications, such as, high modulus of crystalline cellulose combined with the low weight, ${ }^{1}$ not expensive, good biodegradability and renewability. However, the unmodified cellulose is not used for applications because it couldn't be dissolved in most conventional solvents and has not a melting temperature $\left(T_{\mathrm{m}}\right)$. Therefore, the modification of cellulose is required for its applications. ${ }^{2}$

Graft copolymerization $^{3-12}$ with various monomers is the most commonly used method for surface modification of cellulose, and there are two pathways to accomplish it, just like the surface modification of general substrate particles including organics and inorganics, which are "grafting to" and "grafting from" methods. In recent years, the "grafting from" method has attracted a lot of attention because it can obtain higher grafting density ${ }^{13}$ than the "grafting to" method, and the grafting ratio could also be controlled. This is because it can efficiently overcome the shortcoming of the shielding and steric hindrance effects caused by the polymer chains which were fore-grafted onto the substrate surface when other polymer chains approached to the activity centers on the substrate surface in the "grafting to" method. And if the surface graft copolymerization was living, the polymerization degree of the polymer chain onto the substrate surface could be controlled by altering the polymerization time or the other reaction conditions. Furthermore, by the active centers existed at the terminals of the polymer chains, the second graft copolymerization with different monomer could occur and thus the block copolymers could be formed. Thereby the property of the grafts on the substrate surface could be controlled and tailored. The macro-initiators synthesized by combining the initiator bonds onto the particles surface were commonly used as the substrates for the "grafting from" surface graft copolymerization. Among these macro-initiators, the ones used for ATRP have been widely studied in recent years.

ATRP was discovered independently by Matyjaszewski group $^{14,15}$ and Sawamoto group ${ }^{16,17}$ respectively in 1995. It has been extensively studied and used because it possesses many unique advantages and could be as a versatile tool to create polymers with low polydispersity and controlled molecular weight. On the other hand, the terminal halogens of the graft copolymers synthesized through ATRP were still active even over a long time period, ${ }^{1}$ and thus could be as initiators to begin the polymerization of a second vinyl monomer when new ligand and new catalyst were added. So it might be saying that the "grafting from" method has been achieving further development with the appearance of ATRP.

In previous studies, we reported the development of biodegradable plastics ${ }^{18,19}$ synthesized by using waste pulp that was produced by paper manufacturer and usually thrown 
away as waste after treatment. In this study, we used microcrystalline cellulose as the starting material, and modified it by using ATRP and ROP reactions. As the vinyl monomer for ATRP, we used EMO which is a sort of environment-friendly material produced from $\mathrm{C} 1$ chemistry and could be used in stead of epoxy resin. For further modification of the graft copolymers produced through ATRP and the second ATRP, ${ }^{7}$ we carried out the ROP of the aliphatic cyclic esters of CL and LLA by using the hydroxyl groups which were unmodified after ATRP and remained in cellulose glucose units as the initiators. ${ }^{20-22}$ Although the solubility of the products was poor in many conventional solvents, the various measurement results proved the proceeding of the reactions. Because CL and LLA are both environment-friendly materials with excellent biocompatibility and biodegradability, our study could deliver the expected result to the development of green sustainable materials.

\section{EXPERIMENTAL}

\section{Materials}

Microcrystalline cellulose was donated by Murakami Shoji Co., Ltd. EMO was supplied friendly by Ube Industries Ltd., and used after distillation under reduced pressure. MMA was purchased from Nacalai Tesque, Inc. and used after distillation under reduced pressure. CL was purchased from SigmaAldrich Com./Japan, LLA was purchased from Tokyo Chemical Industry Co., Ltd., and both of them were used as received. Solvents for all the reactions were purified by conventional method. The other reagents were used without further purification.

Synthesis of Cell-ClAc. Cell-ClAc was synthesized through a method referenced to the paper reported by A. I. Martin et al., ${ }^{23}$ and a typical procedure was as follows: Cellulose $(2.0 \mathrm{~g}$, $12.4 \mathrm{mmol}$ of anhydrous glucose unit) was introduced into a three-neck flask and dried by using a vacuum pump and a drier. Then a mixture of DMAc $(100 \mathrm{~mL})$ and $\mathrm{LiCl}(10.0 \mathrm{~g})$ was added into it. After stirring under nitrogen atmosphere at $145^{\circ} \mathrm{C}$ for $1 \mathrm{~h}$, the mixture was additionally stirred at $60^{\circ} \mathrm{C}$ to a homogeneous state. Then pyridine $(10 \mathrm{~mL}, 124 \mathrm{mmol})$ was added into the flask followed by chloroacetyl chloride $(9.8 \mathrm{~mL}$, $124 \mathrm{mmol}$ ) adding dropwise. After the reactant was stirred at room temperature for $10 \mathrm{~h}$, the result mixture was transferred dropwise into a large amount of distilled water. After stirring and filtration, the residual was purified by using THF/ $\mathrm{H}_{2} \mathrm{O}(1 / 10, \mathrm{v} / \mathrm{v})$ three times. The resultant was dried in vacuum at $40^{\circ} \mathrm{C}$ to a constant weight.

Synthesis of Cell-PEMO and Cell-PMMA. A typical procedure for the operation was as follows: $\mathrm{CuBr}(0.18 \mathrm{~g}, 1.25$ mmol) and $N, N, N^{\prime}, N^{\prime}$-tetramethylethylenediamine $(0.44 \mathrm{~g}, 3.75$ mmol) were charged into a radical polymerization tube equipped with a magnetic stir bar and stirred under $\mathrm{N}_{2}$ atmosphere for $15 \mathrm{~min}$. Then Cell-ClAc $(0.3 \mathrm{~g}, 1.25 \mathrm{mmol})$, monomer (EMO or MMA, $11.25 \mathrm{mmol})$, and DMF $(10 \mathrm{~mL})$ were added into the tube. The reactant system was degassed by three freeze-pump-thaw cycles to remove traces of oxygen subsequently. After this, the tube was immersed into an oil bath at thermostatic temperature of $130^{\circ} \mathrm{C}$, and the reaction was allowed to proceed for a definite time. Then the tube was opened and the reactant mixture was cooled down rapidly by ice-water. The mixture was transferred into distilled water, stirred and filtrated, then the residue obtained was thrown into a mixture solvent of $\mathrm{H}_{2} \mathrm{O} / \mathrm{MeOH} / \mathrm{HCl}_{\mathrm{aq}(0.1 \mathrm{~N})}(20 / 20 / 1$, v/v/v). After stirring and filtration, the residue was purified by methanol, chloroform, and acetone, sequentially. The resultant was dried under vacuum at $40^{\circ} \mathrm{C}$ to a constant weight.

Synthesis of Cell-(PEMO-b-PMMA) and Cell-(PMMA-bPEMO). A typical procedure for synthesis of Cell-(PEMO$b$-PMMA) was as follows: $\mathrm{CuCl}(0.031 \mathrm{~g}, 0.32 \mathrm{mmol})$ and $\quad N, N, N^{\prime}, N^{\prime \prime}, N^{\prime \prime}$-pentamethyldiethylenetriamine $\quad(0.164 \mathrm{~g}$, $0.95 \mathrm{mmol}$ ) were charged into a Schlenk tube equipped with a magnetic stir bar and stirred under $\mathrm{N}_{2}$ atmosphere for $15 \mathrm{~min}$, then Cell-PEMO $(0.078 \mathrm{~g}, 0.32 \mathrm{mmol})$ and MMA $(3.78 \mathrm{~g}$, $37.80 \mathrm{mmol}$ ) were added into the tube. The vessel was evacuated by aspirator and back-filled with $\mathrm{N}_{2}$-gas three times to remove oxygen traces for an inert reaction atmosphere. Then the tube was immersed into an oil bath prethermostated at $70{ }^{\circ} \mathrm{C}$ for polymerization. After a prescribed time, the reactant mixture was cooled down and transferred into distilled water. Stirred and filtrated, the obtained residue was thrown into a mixture solvent of $\mathrm{H}_{2} \mathrm{O} / \mathrm{MeOH} / \mathrm{HCl}_{\mathrm{aq}(0.1 \mathrm{~N})}(20 / 20 / 1$, v/v/v). After stirring and filtration, the residue was purified through a sufficient removal of PMMA homopolymer by washing with chloroform and acetone. And then the purified product was dried under vacuum at $40{ }^{\circ} \mathrm{C}$ to a constant weight.

The operational procedure for preparation of Cell-(PMMA$b$-PEMO) was similar as Cell-(PEMO- $b$-PMMA) without the differences of Cell-PMMA as initiator, and EMO as monomer in the ATRP process, and also of that a centrifuge separator was used for the product purification.

Synthesis of Cell-PEMO-PCL and Cell-PEMO-PLLA. A typical procedure for operation was as follows: EMO (3.482 g, $18.90 \mathrm{mmol}$ ) and CE (CL or L-LA, $1.58 \mathrm{mmol}$ ) were charged into a Schlenk tube equipped with a magnetic stir bar and stirred under $\mathrm{N}_{2}$ atmosphere for $15 \mathrm{~min}$. $N, N, N^{\prime}, N^{\prime \prime}, N^{\prime \prime}$-pentamethyldiethylenetriamine $\quad(0.165 \mathrm{~g}, \quad 0.95 \mathrm{mmol}), \quad \mathrm{CuBr}_{2}$ $(0.07 \mathrm{~g}, \quad 0.32 \mathrm{mmol})$, Cell-ClAc $(0.116 \mathrm{~g}, 0.32 \mathrm{mmol})$, and DMF $(10 \mathrm{~mL})$ were added into the tube and stirred under $\mathrm{N}_{2}$ atmosphere for another $15 \mathrm{~min} . \mathrm{Sn}(\mathrm{Oct})_{2}(0.014 \mathrm{~g}, 0.04 \mathrm{mmol})$ was added to the reactant mixture subsequently. The tube was evacuated by aspirator and back-filled with $\mathrm{N}_{2}$-gas three times to remove oxygen traces for an inert reaction atmosphere. After a sufficient stirring of the reactant mixture for $60 \mathrm{~min}$, the tube was placed into an oil bath prethermostated at $130{ }^{\circ} \mathrm{C}$. The reaction was allowed to continue for a prescribed time. Then, the mixture was cooled down and transferred into a mixed solvent of $\mathrm{H}_{2} \mathrm{O} / \mathrm{MeOH} / \mathrm{HCl}_{\mathrm{aq}(0.1 \mathrm{~N})}(20 / 20 / 1, \mathrm{v} / \mathrm{v} / \mathrm{v})$. After stirring and filtration, the residue was thrown into another mixed solvent of $\mathrm{MeOH} /$ Toluene (7/3, v/v) again for purification. The insoluble part of this mixture solvent was washed by acetone three times. Then, the obtained product was dried in vacuum at room temperature to a constant weight. 


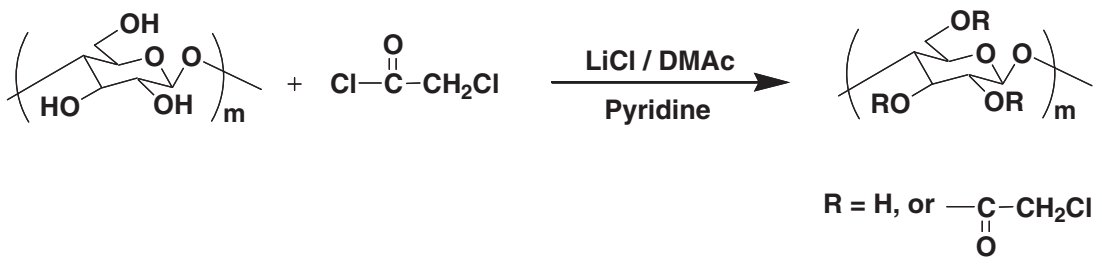

Scheme 1. Synthesis of Cell-CIAc.

Synthesis of Cell-PMMA-PCL and Cell-PMMA-PLLA. The operational procedures for preparation of Cell-PMMA-PCL and Cell-PMMA-PLLA were similar to Cell-PEMO-PCL and Cell-PEMO-PLLA, respectively.

Synthesis of Cell-(PEMO-b-PMMA)-PCL and Cell-(PEMO-bPMMA)-PLLA. The operational procedure for preparation of Cell-(PEMO- $b$-PMMA)-PCL and Cell-(PEMO- $b$-PMMA)PLLA were similar as Cell-PMMA-PCL and Cell-PMMAPLLA without the difference of Cell-PEMO as initiator.

Synthesis of Cell-(PMMA-b-PEMO)-PCL and Cell-(PMMA-bPEMO)-PLLA. The operational procedures for preparation of Cell-(PMMA- $b$-PEMO)-PCL and Cell-(PMMA- $b$-PEMO)PLLA were similar as Cell-PEMO-PCL and Cell-PEMOPLLA without the difference of Cell-PMMA as initiator.

\section{Measurements}

IR spectra were obtained by using a JASCO FT/IR 4100 Fourier Transform Infrared Spectrometer. Thermogravimetric and differential thermal analyses (TG/DTA) were performed on a Seiko Instruments SSC/5200 TG/DTA 220. The operating conditions in an open-aluminum pan were as follows: Sample weight, $10 \mathrm{mg}$; heating rate, $10^{\circ} \mathrm{C} / \mathrm{min}$; and nitrogen gas flow rate, $100 \mathrm{~mL} / \mathrm{min}$. Differential Scanning Calorimetry (DSC) measurements were accomplished on a DSC 3100 equipped with MTC 1000S (MAC Science). The operating conditions in a sealed-aluminum pan were as follows: Sample weight, $10 \mathrm{mg}$; heating rate, $10^{\circ} \mathrm{C} / \mathrm{min}$; and in air atmosphere. The X-ray diffraction patterns were recorded by using a Shimadzu X-ray diffractometer XD-D1. For confirming the melting temperatures of the products, an Olympus BHS-751-P optical polarizing microscope equipped with a Mettler FP82HT hot stage and a Mettler FP80HT central processor was used. And for the crystal observation of the products, a quarter wavelength plate was used on the same Olympus equipment.

\section{RESULTS AND DISCUSSION}

It is known that cellulose is a very useful material, and the modification on it is the premise for its application. For the modification, a great deal of study on the reaction medium ${ }^{24}$ has been carrying out. In many cases, the homogeneous medium conditions is helpful to the reaction, and a better modification effect could be obtained by it. In the preparation of Cell-ClAc, a DMAc/LiCl mixture was used as the medium and the reaction proceeded in homogeneous conditions (Scheme 1). The IR spectra of Cell-ClAc and virgin cellulose were shown in Figure 1. The presence of two new bands at

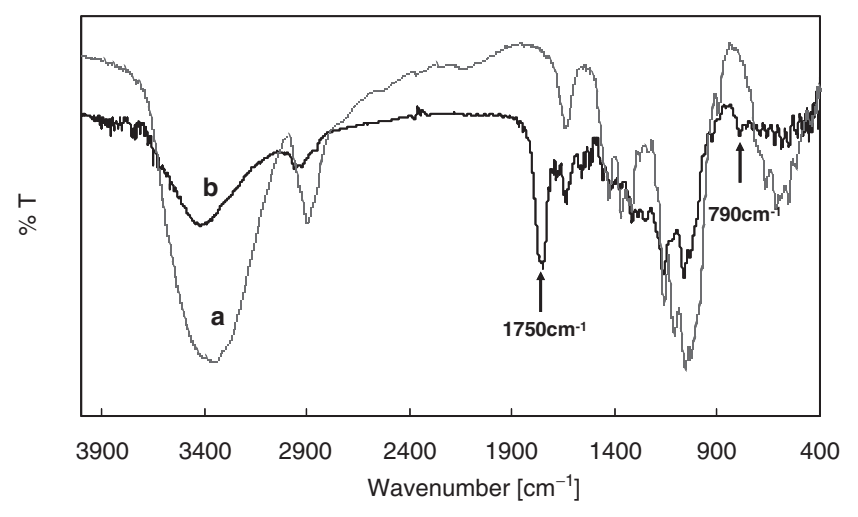

Figure 1. IR spectra of (a) Cellulose and (b) Cell-CIAc.

$1750 \mathrm{~cm}^{-1}$ and $790 \mathrm{~cm}^{-1}$ attributed to $\mathrm{C}=\mathrm{O}$ and $\mathrm{C}-\mathrm{Cl}$ stretching respectively in the spectrum of Cell-ClAc, whereas at which there is no band in virgin cellulose spectrum. This indicates that the chloroacetyl groups have been covalently attached to cellulose. Flame reaction of the Cell-ClAc also confirmed the conclusion. Because of the low solubility of the Cell-ClAc, we couldn't calculate the substitute degree by the ${ }^{1} \mathrm{H}$ NMR determination. A gravimetric method and a titrimetric method ${ }^{7,24}$ were used to determined the substitute degree, and nearly the same value (DS $=2.1$ ) was obtained by the two methods.

Cell-ClAc as macroinitiator was used for the ATRP of EMO. And as a reference, the ATRP of MMA was also carried out (Scheme 2). From the IR spectra of Cell-PEMO and Cell$\mathrm{ClAc}$ (the figure was not shown), the variation of the bands in range of $2850-2960 \mathrm{~cm}^{-1}$ corresponds to methene and methyl stretching, and the shifting of the peak attributed to carbonyl stretching from $1750 \mathrm{~cm}^{-1}$ to $1730 \mathrm{~cm}^{-1}$, and the appearance of the peaks at $1476 \mathrm{~cm}^{-1}$ and $1384 \mathrm{~cm}^{-1}$ due to methyl bending vibration, and the appearance of the peak at $985 \mathrm{~cm}^{-1}$ caused by the stretching of the ether bond in the oxetane cycle were all the important signals for Cell-PEMO. The influencing factors for ATRP of EMO and ATRP of MMA were also investigated by altering the reaction conditions, and the synthetic conditions and results were summaried in Table I. Because the graft copolymers obtained were insoluble in common solvents, the NMR determination could not be performed. The evaluation of the polymerization efficiency was carried out by the yields of the corresponding reactions, and also by the scales of the related peaks in the corresponding IR spectra. 


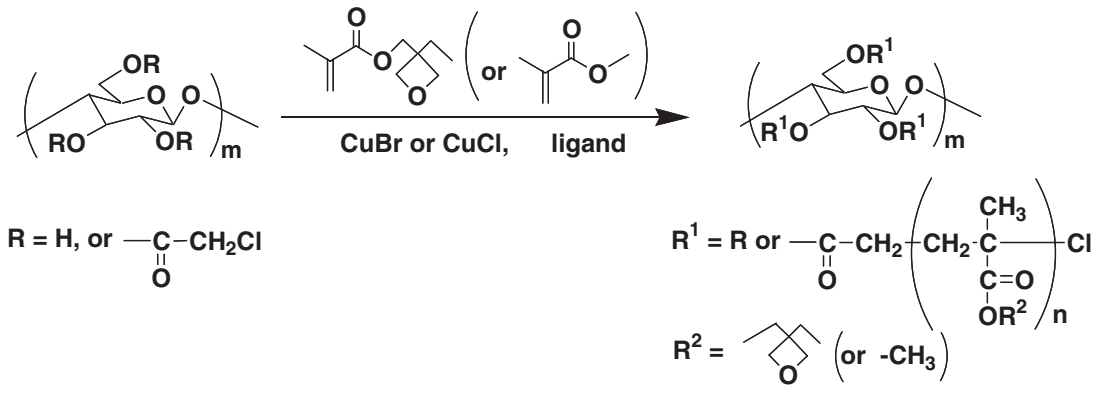

Scheme 2. Synthesis of cellulose graft copolymers by ATRP of EMO or MMA.

Table I. Synthesis of Cell-PEMO and Cell-PMMA graft copolymers

\begin{tabular}{|c|c|c|c|c|c|c|c|c|c|}
\hline Run & $\begin{array}{l}\text { Cell-CIAc } \\
{[\mathrm{g}(\mathrm{mmol})]}\end{array}$ & $\begin{array}{c}\text { Cat. } \\
{[\mathrm{g}(\mathrm{mmol})]}\end{array}$ & $\begin{array}{c}\text { Ligand } \\
{[\mathrm{g}(\mathrm{mmol})]}\end{array}$ & $\begin{array}{l}\text { Monomer } \\
{[\mathrm{g}(\mathrm{mmol})]}\end{array}$ & $\begin{array}{l}\text { Solv. } \\
\text { (mL) }\end{array}$ & $\begin{array}{c}\text { Temp. } \\
\left({ }^{\circ} \mathrm{C}\right)\end{array}$ & $\begin{array}{l}\text { Time } \\
\text { (h) }\end{array}$ & $\begin{array}{l}\text { Yield } \\
(\mathrm{g})\end{array}$ & $\begin{array}{l}\text { Mole ratio } \\
\left.(\mathrm{I}: \mathrm{C}: \mathrm{L}: M)^{\mathrm{i}}\right)\end{array}$ \\
\hline 1 & $0.30(1.25)$ & $0.18(1.25)^{\mathrm{a})}$ & $0.44(3.75)^{\mathrm{c})}$ & $1.38(7.50)^{\mathrm{e})}$ & $10^{\mathrm{g})}$ & 130 & 21 & 0.31 & $1: 1: 3: 6$ \\
\hline 2 & $0.30(1.25)$ & $0.18(1.25)^{\mathrm{a})}$ & $0.44(3.75)^{\mathrm{c})}$ & $2.07(11.25)^{\mathrm{e})}$ & $10^{g)}$ & 130 & 21 & 0.32 & 1:1:3:9 \\
\hline 3 & $0.30(1.25)$ & $0.18(1.25)^{\mathrm{a})}$ & $0.64(3.75)^{d)}$ & $2.07(11.25)^{\mathrm{e})}$ & $10^{g)}$ & 130 & 21 & 0.33 & $1: 1: 3: 9$ \\
\hline 4 & $0.07(0.31)$ & $0.05(0.31)^{a)}$ & $0.16(0.94)^{d)}$ & $\left.3.50(18.75)^{\mathrm{e}}\right)$ & - & 110 & 21 & 0.13 & $1: 1: 3: 60$ \\
\hline 5 & $0.07(0.31)$ & $0.03(0.31)^{a)}$ & $0.16(0.94)^{d)}$ & $1.71(9.30)^{\mathrm{e})}$ & $10^{g)}$ & 130 & 21 & 0.09 & 1:1:3:30 \\
\hline 6 & $0.30(1.25)$ & $0.18(1.25)^{\mathrm{a})}$ & $0.44(3.75)^{\mathrm{c})}$ & $1.38(7.50)^{\mathrm{e})}$ & $10^{\mathrm{h})}$ & 130 & 21 & 0.31 & $1: 1: 3: 6$ \\
\hline 7 & $0.15(0.63)$ & $0.09(0.63)^{b)}$ & $0.22(1.88)^{c)}$ & $1.04(5.63)^{\mathrm{e})}$ & $10^{\mathrm{h})}$ & 130 & 21 & 0.16 & $1: 1: 3: 9$ \\
\hline 8 & $0.15(0.63)$ & $0.09(0.63)^{b)}$ & $0.33(1.88)^{d)}$ & $1.04(5.63)^{\mathrm{e})}$ & $10^{\mathrm{h})}$ & 130 & 21 & 0.17 & $1: 1: 3: 9$ \\
\hline 9 & $0.30(1.25)$ & $0.18(1.25)^{a)}$ & $0.44(3.75)^{\mathrm{c})}$ & $7.50(75.00)^{f)}$ & $10^{\mathrm{g})}$ & 130 & 20 & 0.32 & $1: 1: 3: 60$ \\
\hline 10 & $0.30(1.25)$ & $0.18(1.25)^{\mathrm{a})}$ & $0.64(3.75)^{d)}$ & $1.13(11.25)^{f)}$ & $10^{g)}$ & 130 & 20 & 0.31 & $1: 1: 3: 9$ \\
\hline 11 & $0.15(0.63)$ & $0.09(0.63)^{a)}$ & $0.32(1.88)^{d)}$ & $\left.3.79(37.50)^{f}\right)$ & 10g) & 100 & 21 & 0.18 & 1:1:3:60 \\
\hline
\end{tabular}

a) $\mathrm{CuBr}$. b) $\mathrm{CuCl}$. c) TMEDA: $N, N, N^{\prime}, N^{\prime}$-tetramethylethylenediamine. d) PMDETA: $N, N, N^{\prime}, N^{\prime \prime}, N^{\prime \prime}$-Pentamethyldiethylenetriamine. e) EMO: 3-ethyl-3-methacryloyloxymethyloxetane. ${ }^{\text {f) }} \mathrm{MMA}$ : methyl methacrylate. ${ }^{\mathrm{g})} \mathrm{DMF} .{ }^{\text {h) }} \mathrm{DMSO}$. ${ }^{\mathrm{i}}$ Molar ratio of $[\text { Initiator }]_{0} /[\text { Cat }]_{0} /[\text { Ligand }]_{0} /[\mathrm{Monomer}]_{0}$.

As for ligands of ATRP, because the multidentate amines such as $N, N, N^{\prime}, N^{\prime}$-tetramethylethylenediamine (TMEDA) and $N, N, N^{\prime}, N^{\prime \prime}, N^{\prime \prime}$-pentamethyldiethylenetriamine (PMDETA) have many advantages compared with 2,2'-bipyridine and its derivatives. ${ }^{25}$ For this reason, these amines were used as the ligands in our copper-catalyzed ATRP. A little larger amount of the product was obtained when the tridentate amine of PMDETA was used as the ligand than the case of the bidentate one of TMEDA was used. The same result was obtained in the repeating experiments. This is compatible with a previous report by Jianhui et al. ${ }^{25}$

As the solvent for the ATRPs of EMO and of MMA, DMSO and anisole were also used besides of DMF. And because both of them were polar solvents such as DMF, the PMDETA ligand was also used in the two solvent mediated ATRP processes.

When DMSO was used as the solvent for the ATRP process, a higher viscosity was observed, compared with the case of DMF as solvent. This was probably ascribed to the formation of very active mononuclear $\left[\mathrm{Cu}(\text { ligand })_{\mathrm{n}}(\mathrm{DMSO})_{\mathrm{m}}\right]^{+}$catalyst in DMSO caused by the competitive complexation of DMSO and ligand. Specifically, the coordination of the oxygen atoms of DMSO at the copper was in competition with the ligand. And thereby the polymerization rate increased because the nature of $\mathrm{Cu}(\mathrm{I})$ catalyst was changed by the catalyst structure according to the literature data reported by S. Monge et al. ${ }^{26}$

The ATRP processes using EMO and MMA as monomers at $100{ }^{\circ} \mathrm{C}$ in DMF solvent were also performed respectively. The ATRP of MMA occurred whereas the ATRP of EMO did not proceed. This may be due to the following two reasons: One was that EMO had a larger bulky volume than MMA. Therefore, EMO was not easy to approach the active centers for polymerization. Another reason was that the reaction temperature was not enough. However, the ATRP of EMO proceeded successfully at $130{ }^{\circ} \mathrm{C}$.

On the other hand, the ATRP processes of EMO and MMA at $100{ }^{\circ} \mathrm{C}$ in anisole solvent were also carried out respectively. As the result, the ATRP of EMO did not occur, and for the ATRP of MMA, a delicate shift of the carbonyl peak in IR spectrum of the product was found when compared with the Cell-ClAc initiator spectrum. This indicated that the ATRP of MMA occurred. However the polymerization was not sufficient. Because anisole had a weaker polarity than DMF, this suggested that the polarity level of DMF was appropriate for our ATRP processes.

It was reported by many researchers that a better effect could be obtained by using the halogen exchange ${ }^{27,28}$ technique in ATRP process. But this phenomenon was not found evidently in our experiments. Even this, the operation of halogen exchange was still used in our ATRP process.

The feeding ratio of the macroinitiator, the copper catalyst and the ligand was chosen at 1:1:3 in the processes, and the amount of monomer was selected at 6, 9, 30 and 60 times of the macroinitiator used, respectively. The yield of the products did not increase proportionably with increasing the additive amount of monomer, and it seemed a saturation existed in the polymerization process. The attachment of the monomers to the Cell-ClAc backbone may be getting difficult gradually. 


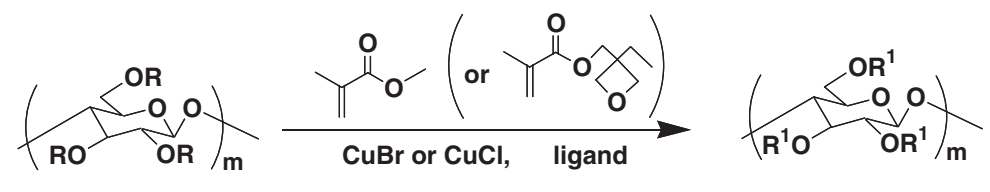

$$
\begin{gathered}
\mathrm{R}=\mathrm{H}, \text { or }-\underset{\Pi 1}{\mathrm{C}}-\mathrm{CH}_{2} \mathrm{Cl} \\
\text { or, }-\stackrel{\mathrm{C}}{\mathrm{C}}-\mathrm{CH}_{2} \text {-PEMO } \\
\text { (or, }-\stackrel{\mathrm{O}}{\mathrm{C}}-\mathrm{CH}_{2} \text {-PMMA) }
\end{gathered}
$$$$
R^{1}=R \text { or } \stackrel{O}{\text { C }}-\mathrm{CH}_{2}-\text { PEMO-b-PMMA }
$$

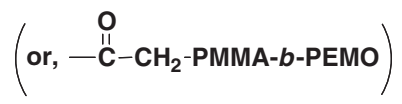

\begin{tabular}{|c|c|c|c|c|c|c|c|c|}
\hline Run & $\begin{array}{c}\text { macro-initiator } \\
{[\mathrm{g}(\mathrm{mmol})]}\end{array}$ & $\begin{array}{c}\text { Cat. })^{e} \\
{[g(m m o l)]}\end{array}$ & $\begin{array}{c}\text { Ligand } \\
{[\mathrm{g}(\mathrm{mmol})]}\end{array}$ & $\begin{array}{l}\text { monomer } \\
{[\mathrm{g}(\mathrm{mmol})]}\end{array}$ & $\begin{array}{c}\text { Temp. } \\
\left({ }^{\circ} \mathrm{C}\right)\end{array}$ & $\begin{array}{l}\text { Time } \\
\text { (h) }\end{array}$ & $\begin{array}{l}\text { Yield } \\
\text { (g) }\end{array}$ & $\begin{array}{l}\text { Mole ratio } \\
(\text { (I:C:L:M })^{\mathrm{j})}\end{array}$ \\
\hline 1 & $0.065(0.16)^{a)}$ & $0.02(0.16)$ & $0.08(0.47)^{f)}$ & $0.96(9.60)^{\mathrm{h})}$ & 70 & 21 & 0.097 & 1:1:3:60 \\
\hline 2 & $0.078(0.32)^{b)}$ & $0.031(0.32)$ & $0.164(0.95)^{f)}$ & $3.78(37.80)^{\mathrm{h})}$ & 70 & 46 & 0.092 & $1: 1: 3: 120$ \\
\hline 3 & $0.095(0.16)^{c}$ & $0.015(0.16)$ & $0.081(0.47)^{f)}$ & $0.931(9.30)^{\mathrm{h})}$ & 70 & 50 & 0.095 & $1: 1: 3: 60$ \\
\hline 4 & $0.130(0.32)^{d}$ & $0.030(0.32)$ & $\left.0.110(0.94)^{g}\right)$ & $3.540(19.2)^{i}$ & 70 & 46 & 0.313 & $1: 1: 3: 60$ \\
\hline
\end{tabular}

Scheme 3. The second ATRP of MMA or EMO initiated by Cell-PEMO or Cell-PMMA.

Table II. Synthesis of Cell-(PEMO-b-PMMA) and Cell-(PMMA- $b$-PEMO) graft block copolymers

a) Run7 of synthesis of Cell-PEMO and Cell-PMMA graft copolymers. ${ }^{\text {b) }}$ Run5 of synthesis of Cell-PEMO and Cell-PMMA graft copolymers. ${ }^{\text {c) }}$ Run2 of synthesis of Cell-PEMO and Cell-PMMA graft copolymers. d) Run11 of synthesis of Cell-PEMO and Cell-PMMA graft copolymers. e) CuCl. f) PMDETA: $N, N, N^{\prime}, N^{\prime \prime}, N^{\prime \prime}-$ Pentamethyldiethylenetriamine. 9) TMEDA: $N, N, N^{\prime}, N^{\prime}$-tetramethylethylenediamine. h) MMA: methyl methacrylate. i) EMO: 3-ethyl-3-(methacryloyloxy)methyloxetane. j) Molar ratio of [Initiator $]_{0} /[\text { Cat. }]_{0} /[\text { Ligand }]_{0} /[\text { Monomer }]_{0}$.

Because the halogen terminal of the ATRP product remains activity and could play a role as an initiator for another ATRP reaction, the second ATRP of EMO and MMA by using CellPMMA and Cell-PEMO as initiators were performed, respectively (Scheme 3). As mentioned above, in order to achieve a better effect, the halogen exchange technique was also utilized in the polymerization processes, although the effect was not evident in our experiments. In addition, a more severe reaction conditions of bulk ${ }^{29}$ than solvent conditions was used based on the consideration of that the reaction was the second one. The synthetic conditions and the results were summarized in Table II.

It is known, in the preparation of block copolymer, the addition sequence of the monomer also influenced the result of the product. ${ }^{30}$ This phenomenon was also found in our experiments. In the synthesis of Cell-(PEMO- $b$-PMMA), the reactant mixture solidified during the reaction period. This might result from the fact that the homopolymerization of MMA also occured simultaneously during the second ATRP of MMA. In addition, the polymerization of MMA was easier than the EMO, and the bulky graft chain of PEMO in CellPEMO inhibited the second ATRP of MMA with the CellPEMO. After removal of PMMA from the product by wash with chloroform and acetone, the obtained product was analyzed by FT-IR to confirm the formation of Cell-(PEMO$b$-PMMA). For the synthesis of Cell-(PMMA- $b$-PEMO), a more satisfied result than the preparation of Cell-(PEMO- $b$ PMMA) was obtained. The reason for this might be ascribed to the followings. First, in the preparation of Cell-PMMA, a smaller volume of MMA than EMO makes it easily and morely

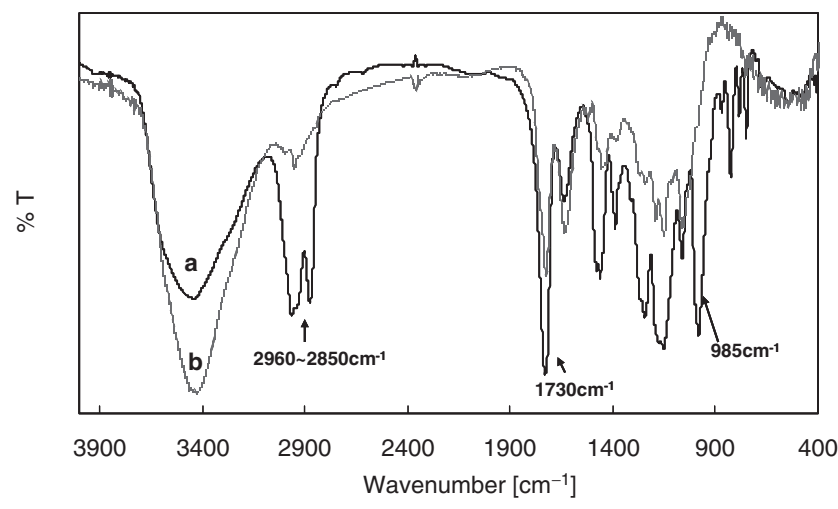

Figure 2. IR spectra of (a) Cell-(PMMA-b-PEMO) and (b) Cell-PMMA.

reached to Cell-ClAc for polymerization due to the less steric hindrance. Consequently a longer chain of PMMA could be formed on the Cell-ClAc backbone. By the benefit of this longer PMMA chain, the EMO monomer could easily reached to the Cell-PMMA for polymerization thanks to a less steric hindrance. The IR spectra of Cell-(PMMA- $b$-PEMO) and the Cell-PMMA initiator were shown in Figure 2.

In many cases, the substitution of the hydroxyl groups in glucose units of cellulose was hardly to achieve fully, so the unsubstituted hydroxyl groups existed in these cellulose derivatives. As known, the hydroxyl group could be an initiator to start ROP of a cyclic ester compound. Based on this consideration, the ROP of CL and LLA were carried out by using the products synthesized above. For the reaction conditions, the literature data reported by $\mathrm{D}$. Wu et al. ${ }^{31}$ was 
Table III. Synthesis of cellulose graft copolymers and cellulose graft block copolymers

\begin{tabular}{|c|c|c|c|c|c|c|c|c|c|c|}
\hline Run & $\begin{array}{c}\text { Initiator } \\
{[\mathrm{g}(\mathrm{mmol})]}\end{array}$ & $\begin{array}{l}\left.\text { Ligand }^{\mathrm{e}}\right) \\
{[\mathrm{g}(\mathrm{mmol})]}\end{array}$ & $\begin{array}{c}\text { Cat. } \\
{[\mathrm{g}(\mathrm{mmol})]}\end{array}$ & $\begin{array}{c}\mathrm{Sn}(\mathrm{Oct})_{2} \\
{[\mathrm{~g}(\mathrm{mmol})]}\end{array}$ & $\begin{array}{c}\text { DMF } \\
\mathrm{mL}\end{array}$ & $\begin{array}{c}\text { CE } \\
{[\mathrm{g}(\mathrm{mmol})]}\end{array}$ & $\begin{array}{l}\text { Monomer } \\
{[\mathrm{g}(\mathrm{mmol})]}\end{array}$ & $\begin{array}{c}\text { Temp. } \\
\left({ }^{\circ} \mathrm{C}\right)\end{array}$ & $\begin{array}{l}\text { Time } \\
\text { (h) }\end{array}$ & $\begin{array}{c}\text { Yield } \\
\text { (g) }\end{array}$ \\
\hline 1 & $0.116(0.32)^{\mathrm{a})}$ & $0.165(0.95)$ & $0.07(0.32)^{f)}$ & $0.014(0.04)$ & 10 & $0.180(1.58)^{\mathrm{h})}$ & $3.482(18.90)^{j)}$ & 130 & 56 & 0.139 \\
\hline 2 & $0.116(0.32)^{a)}$ & $0.165(0.95)$ & $0.07(0.32)^{f)}$ & $0.014(0.04)$ & 10 & $0.227(1.58)^{\mathrm{i})}$ & $3.482(18.90)^{\mathrm{j})}$ & 130 & 48 & 0.148 \\
\hline 3 & $0.116(0.32)^{a)}$ & $0.165(0.95)$ & $0.07(0.32)^{f)}$ & $0.014(0.04)$ & 10 & $0.180(1.58)^{\mathrm{h})}$ & $1.892(18.90)^{\mathrm{k}}$ & 130 & 56 & 0.324 \\
\hline 4 & $0.116(0.32)^{a)}$ & $0.165(0.95)$ & $0.07(0.32)^{f}$ & $0.014(0.04)$ & 10 & $0.227(1.58)^{i}$ & $1.892(18.90)^{\mathrm{k})}$ & 130 & 48 & 0.116 \\
\hline 5 & $0.085(0.32)^{b)}$ & $0.165(0.95)$ & $0.04(0.32)^{g)}$ & $0.014(0.04)$ & 10 & $0.180(1.58)^{\mathrm{h})}$ & $1.892(18.90)^{\mathrm{k}}$ & 130 & 48 & 0.214 \\
\hline 6 & $0.075(0.32)^{c)}$ & $0.165(0.95)$ & $0.04(0.32)^{g)}$ & $0.014(0.04)$ & 10 & $0.227(1.58)^{i}$ & $1.892(18.90)^{\mathrm{k})}$ & 130 & 48 & 0.075 \\
\hline 7 & $0.076(0.31)^{d)}$ & $0.163(0.94)$ & $0.04(0.31)^{\mathrm{g})}$ & $0.042(0.10)$ & 10 & $0.178(1.56)^{\mathrm{h})}$ & $3.455(18.75)^{j)}$ & 130 & 48 & 0.134 \\
\hline 8 & $\left.0.076(0.31)^{d}\right)$ & $0.163(0.94)$ & $0.04(0.31)^{g)}$ & $0.042(0.10)$ & 10 & $0.225(1.56)^{i)}$ & $3.455(18.75)^{\mathrm{j})}$ & 130 & 48 & 0.093 \\
\hline
\end{tabular}

a) Cellulose chloroacetate (Cell-CIAc). ${ }^{\text {b) }}$ Run6 of synthesis of Cell-PEMO and Cell-PMMA graft copolymers. ${ }^{c}$ Run2 of synthesis of Cell-PEMO and Cell-PMMA graft copolymers. d) Run9 of synthesis of Cell-PEMO and Cell-PMMA graft copolymers. e) PMDETA: $N, N, N^{\prime}, N^{\prime \prime}, N^{\prime \prime}-\mathrm{Pentamethyldiethylenetriamine.} \mathrm{f)}$ CuBr . g) $\mathrm{CuCl}_{2} .{ }^{\text {h) }} \mathrm{CL}$ : $\varepsilon$-carprolactone. i) L-LA: L-Lactide. j) EMO: 3-ethyl-3-(methacryloyloxy)methyloxetane. k) MMA: methyl methacrylate.

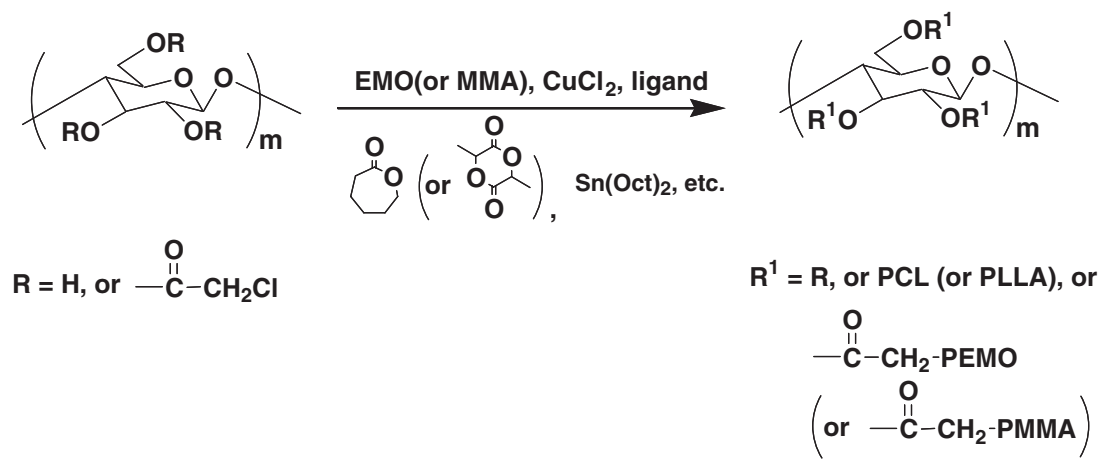

Scheme 4. AGET ATRP of EMO or MMA and ROP of CL or LLA proceed simultaneously in the same reaction system by using the same initiator of Cell-CIAc.

referenced. In the following description, these cellulose derivatives acted as initiators of ROP as well as initiators of ATRP. The reaction conditions and results were summarized in Table III.

At first, the AGET ATRPs of EMO and MMA and the ROPs of CL and LLA in the same reaction system simultaneous$1 y^{31-35}$ by using the same initiator of Cell-ClAc were performed respectively (Scheme 4, run1-4 in Table III). $\mathrm{Sn}(\mathrm{Oct})_{2}$ was used as reducing agent for $\mathrm{Cu}(\mathrm{II})$, and in the meantime, it was also used as catalyst for the ROPs of CEs. According to the reported data $^{36,37}$ of that, in a heterogeneous system, the reactivity order of hydroxyl groups in cellulose glucose unit was $\mathrm{C} 2>\mathrm{C} 6 \gg \mathrm{C} 3$, and however, in a homogeneous system such as $\mathrm{LiCl} / \mathrm{DMAc}$ mixture the order was $\mathrm{C} 6>\mathrm{C} 2 \gg \mathrm{C} 3$. So we considered that the acylation reaction of cellulose mainly occurred at the hydroxyl groups of C6 positions. Accordingly, for the simultaneous ATRP and ROP above, the ATRP reaction mainly occurred at C6 positions of cellulose glucose units judged by the acylation reaction. And the ROP reaction mainly occurred at $\mathrm{C} 2$ positions because of the heterogeneous reaction system. As for confirmation of the products, the FT-IR determination was performed, and the IR spectra of Cell-PEMO-PLLA and Cell-ClAc were shown in Figure 3. In the spectrum of Cell-PEMO-PLLA, the peaks around $2960-2850 \mathrm{~cm}^{-1}$ were observed, and these peaks were attributed to the methyl and methylene stretching vibration caused by the introduction of PEMO and PLLA components. In addition, the peak assigned to the ester $\mathrm{C}=\mathrm{O}$ group shifted

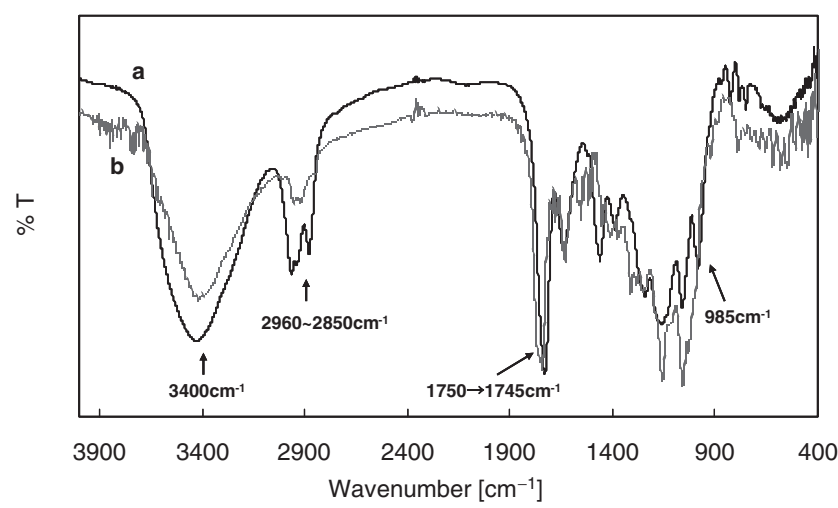

Figure 3. IR spectra of (a) Cell-PEMO-PLLA and (b) Cell-CIAc.

from $1750 \mathrm{~cm}^{-1}$ to $1745 \mathrm{~cm}^{-1}$. And in the spectrum of CellPEMO-PLLA, the absorption peak around $984 \mathrm{~cm}^{-1}$ attributed to the stretching vibration of cyclic ether C-O-C group from oxetane ring was also observed. The measurements of the other products were also carried out by the FT-IR spectrum. Based on these results, the proceeding of ATRP and ROP was confirmed.

In the next, the AGET ATRP reactions of EMO and MMA and the ROP reactions of CL and LLA in the same reaction system simultaneously by using Cell-PEMO (run5-6, in Table III) and Cell-PMMA (run7-8, in Table III) as initiators were carried out respectively (Scheme 5). The FT-IR analyses also showed satisfied results of the reactions. And as an example, the IR spectra of Cell-(PMMA- $b$-PEMO)-PCL and 
Table IV. Thermal properties of cellulose derivatives

\begin{tabular}{|c|c|c|c|c|c|c|c|}
\hline \multirow[t]{2}{*}{ Sample } & \multirow{2}{*}{$\begin{array}{l}T_{\mathrm{g}}^{\mathrm{a})} \\
\left({ }^{\circ} \mathrm{C}\right)\end{array}$} & $T_{\mathrm{g}^{\mathrm{E}}} \mathrm{E}^{\mathrm{b}}$ & $\left.T_{\mathrm{g}^{\mathrm{M}}} \mathrm{c}\right)$ & $T_{\mathrm{g}^{\mathrm{c}}}{ }^{\mathrm{d})}$ & $\left.T_{\mathrm{g}^{\mathrm{L}}} \mathrm{e}\right)$ & \multirow{2}{*}{$\begin{array}{c}W_{\left.500^{f}\right)} \\
(\%)\end{array}$} & \multirow{2}{*}{$\begin{array}{c}T_{\text {dmax }}{ }^{\mathrm{g})} \\
\left({ }^{\circ} \mathrm{C}\right)\end{array}$} \\
\hline & & & & & & & \\
\hline Cell-CIAc & 161.4 & & & & & 74.3 & 277.6 \\
\hline Cell-PEMO & 146.2 & & & & & 95.6 & $317.5,422.3$ \\
\hline Cell-PMMA & 155.1 & & & & & 89.8 & 315.2 \\
\hline Cell-(PEMO- $b$-PMMA) & 200.7 & 161.6 & 130.4 & & & 91.4 & $306.5,473.4$ \\
\hline Cell-(PMMA- $b$-PEMO) & 217.0 & 169.6 & 114.8 & & & 90.4 & 329.7 \\
\hline Cell-PMMA-PCL & 217.2 & & 119.9 & $(-)^{\mathrm{h})}$ & & 81.2 & $230.1,405.0$ \\
\hline Cell-PMMA-PLLA & $(-)^{\mathrm{h})}$ & & 120.1 & & 56.9 & 66.1 & $298.7,348.2$ \\
\hline Cell-PEMO-PCL & 186.4 & 162.9 & & $(-)^{\mathrm{h})}$ & & 62.7 & $301.4,326.6$ \\
\hline Cell-PEMO-PLLA & 197.3 & 166.6 & & & $(-)^{\mathrm{h})}$ & 69.1 & 341.3 \\
\hline
\end{tabular}

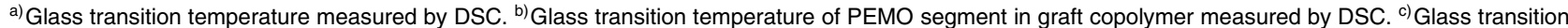
temperature of PMMA segment in graft copolymer measured by DSC. d) Glass transition temperature of PCL fraction in graft copolymer measured by DSC. e) Glass transition temperature of PLLA fraction in graft copolymer measured by DSC. ${ }^{\mathrm{f})}$ Weight loss at $500^{\circ} \mathrm{C}$ determined by TG-DTA. ${ }^{\text {) Temperature at which }}$ the degradation speed is the largest determined by TG-DTG. h) Not be detected.

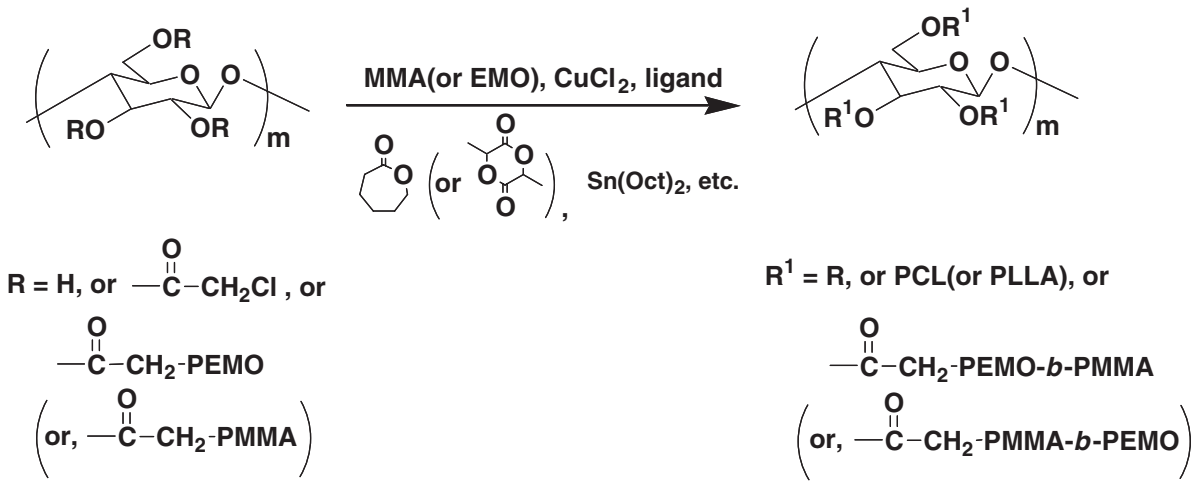

Scheme 5. AGET ATRP of MMA or EMO and ROP of CL or LLA proceed simultaneously in the same reaction system by using the same initiator of Cell-PEMO or Cell-PMMA.

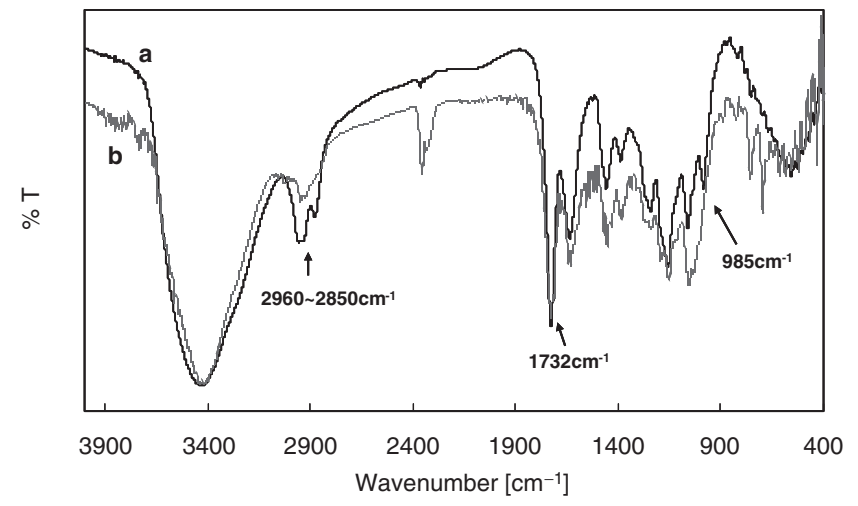

Figure 4. IR spectra of (a) Cell-(PMMA-b-PEMO)-PCL and (b) Cell-PMMA.

Cell-PMMA were shown in Figure 4. In the spectrum of Cell(PMMA- $b$-PEMO)-PCL, the peaks around $2960-2850 \mathrm{~cm}^{-1}$ were observed, and these peaks were attributed to the methyl and methylene stretching vibration caused by the introduction of PEMO and PCL components. In addition, the peak assigned to the ester $\mathrm{C}=\mathrm{O}$ group shifted from $1730 \mathrm{~cm}^{-1}$ to $1732 \mathrm{~cm}^{-1}$ and became larger than that of Cell-PMMA. And in the spectrum of Cell-(PMMA- $b$-PEMO)-PCL, the absorption peak around $984 \mathrm{~cm}^{-1}$ attributed to the stretching vibration of cyclic ether $\mathrm{C}-\mathrm{O}-\mathrm{C}$ group from oxetane ring was also observed.
Thermal analyses of the products were also carried out, and the results were summarized in Table IV. TGA curves of Cellulose, Cell-ClAc, Cell-PEMO, Cell-(PEMO- $b$-PMMA), Cell-PEMO-PCL, and Cell-(PMMA- $b$-PEMO) were shown in Figure 5. As well known, cellulose is a material that has not a melting point temperature, and its glass transition temperature appears at $230{ }^{\circ} \mathrm{C} . .^{38,39}$ Its thermal degradation starting temperature was $290^{\circ} \mathrm{C}^{7,40}$ approximately, and the degradation course shows a narrow temperature range. However, in the TGA curves of these cellulose derivatives, the degradation starting temperatures exhibited lower values than $290^{\circ} \mathrm{C}$ of virgin cellulose, and the thermal degradation courses revealed wide temperature ranges. In addition, as shown in Table IV, the $T_{\mathrm{g}} \mathrm{S}$ of all these cellulose derivatives were lower than $230^{\circ} \mathrm{C}$ of virgin cellulose. These facts also suggested the proceeding of the corresponding reactions.

As shown in Table IV, in different graft copolymers, even though the same segments, the $T_{\mathrm{g}} \mathrm{s}$ of them were different. It could be due to the different segment length of graft polymers caused by the reaction conditions and the interaction between the different segments in the graft copolymer.

Figure 6 was the TG-DTG curves of the Cell-(PEMO- $b$ PMMA). The maximum degradation speed was observed around $306.5^{\circ} \mathrm{C}$ and $473.4{ }^{\circ} \mathrm{C}$, respectively. The degradation course proceeded in two stages approximately, suggested the 


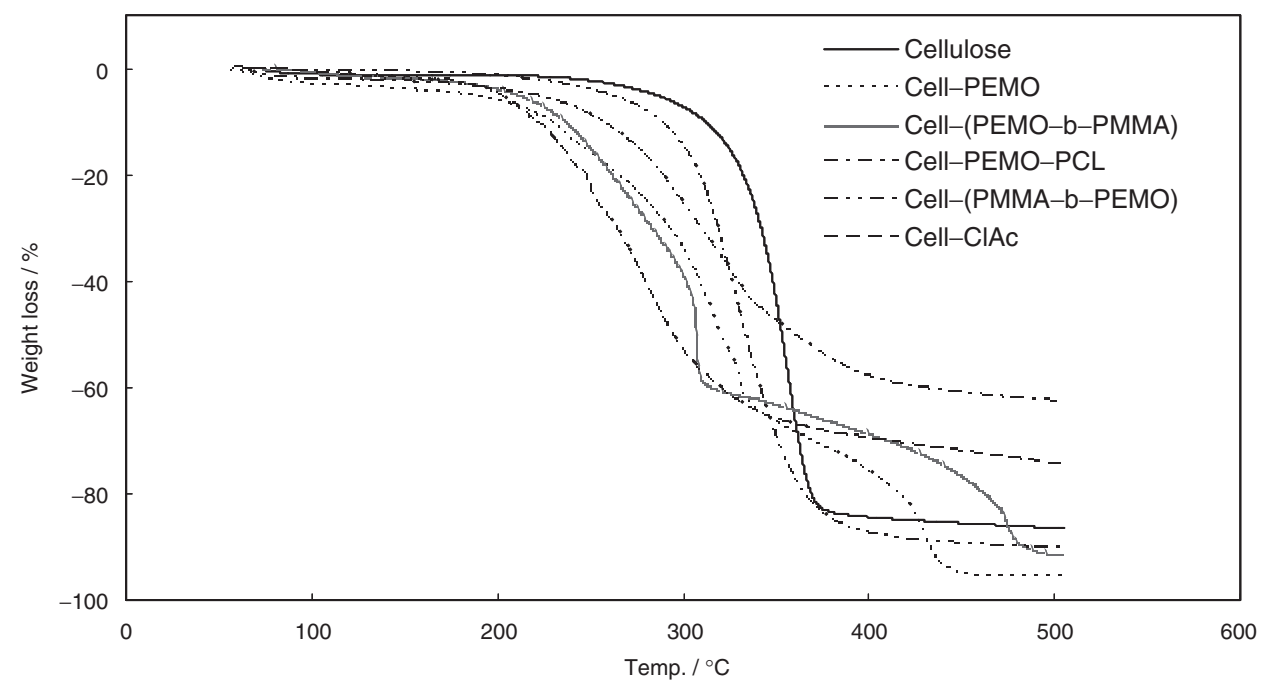

Figure 5. TGA curves of cellulose and cellulose derivatives.

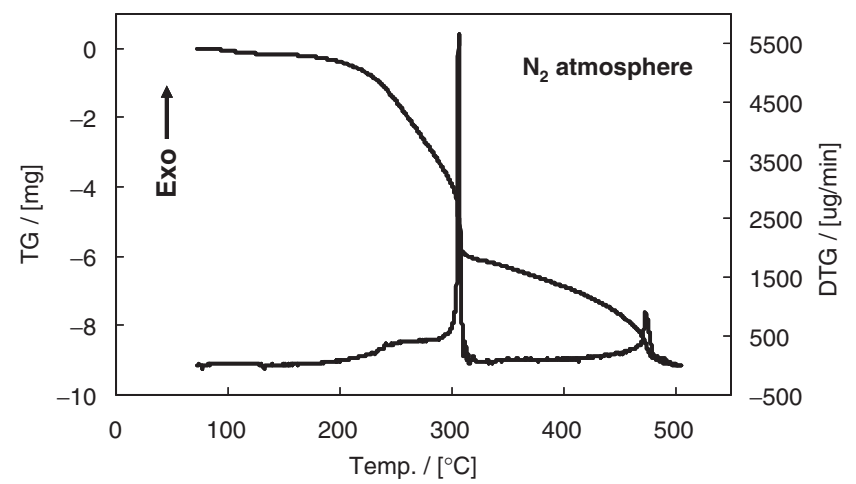

Figure 6. TG-DTG curves of Cell-(PEMO-b-PMMA).

degradation of the PEMO- $b$-PMMA blocks and the cellulose fraction in the graft copolymer. The degradation percentage was $91.4 \%$ when heated it to $500{ }^{\circ} \mathrm{C}$. The thermal properties of the other graft copolymers were shown in Table IV.

The TG-DTA curves of Cell-(PMMA- $b$-PEMO) were shown in Figure 7. The degradation course proceeded in one stage. The baseline shift at about $130^{\circ} \mathrm{C}$ may be ascribed to the $T_{\mathrm{g}}$ of PMMA or PEMO phase. And the two endothermic peaks around $330^{\circ} \mathrm{C}$ and $370^{\circ} \mathrm{C}$ were probably related to the pyrolysis of the PMMA- $b$-PEMO blocks and the cellulose fraction in the graft copolymer.

The DSC thermogram of Cell-(PMMA- $b$-PEMO) and Cell(PEMO- $b$-PMMA) during the first heating cycle were shown in Figure 8 . From these curves the $T_{\mathrm{g}} \mathrm{s}$ of the PEMO segment, the PMMA segment, and the cellulose graft block copolymers were observed, respectively.

In order to confirm $T_{\mathrm{m}} \mathrm{s}$ of the graft copolymers obtained, an Olympus BHS-751-P polarizing microscope equipped with a Mettler FP82HT hot stage and a Mettler FP80HT central processor was used. The $T_{\mathrm{m}} \mathrm{s}$ of all the products were not found in the temperature range of $0-300^{\circ} \mathrm{C}$.

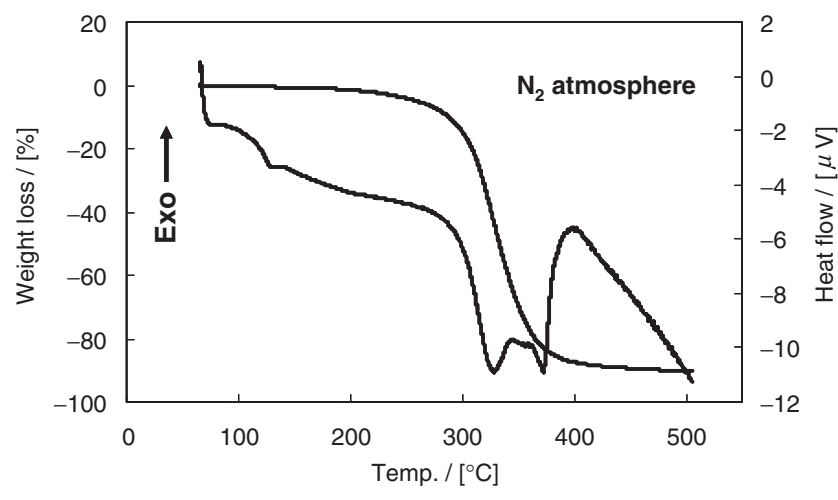

Figure 7. TG-DTA curves of Cell-(PMMA-b-PEMO).

For the crystal observation of the graft copolymers, a quarter wave retardation plate was used on the same Olympus equipment. The bright spots caused by the crystal parts of cellulose in the cellulose derivatives became smaller and smaller in the following order: virgin cellulose, Cell-ClAc, Cell-PEMO, Cell-PMMA, and Cell-(PEMO- $b$-PMMA) (or Cell-PEMO-PCL). It seemed that the result was related to contents of graft chains. Therefore, Cell-(PEMO- $b$-PMMA) and Cell-PEMO-PCL having a high content of graft chains were darker than the others. In addition, Cell-PMMA has smaller spots of cellulose than Cell-PEMO, and the phenomenon indicates that the polymerization of MMA with Cell-ClAc was easier than the case of EMO.

Wide-angle X-ray diffraction (WAXD) measurement of the products were also carried out, and the X-ray diffraction patterns of virgin cellulose I, Cell-ClAc, Cell-PEMO, Cell(PEMO- $b$-PMMA), and Cell-PEMO-PCL were shown in Figure 9. From the comparison of Cell-ClAc and virgin cellulose I, it was found that the characteristic diffraction peaks of virgin cellulose $\mathrm{I}$ at $2 \theta=14.8^{\circ}, 22.1^{\circ}$, and $34.5^{\circ}$ almost disappeared or became broad in the Cell-ClAc pattern. 


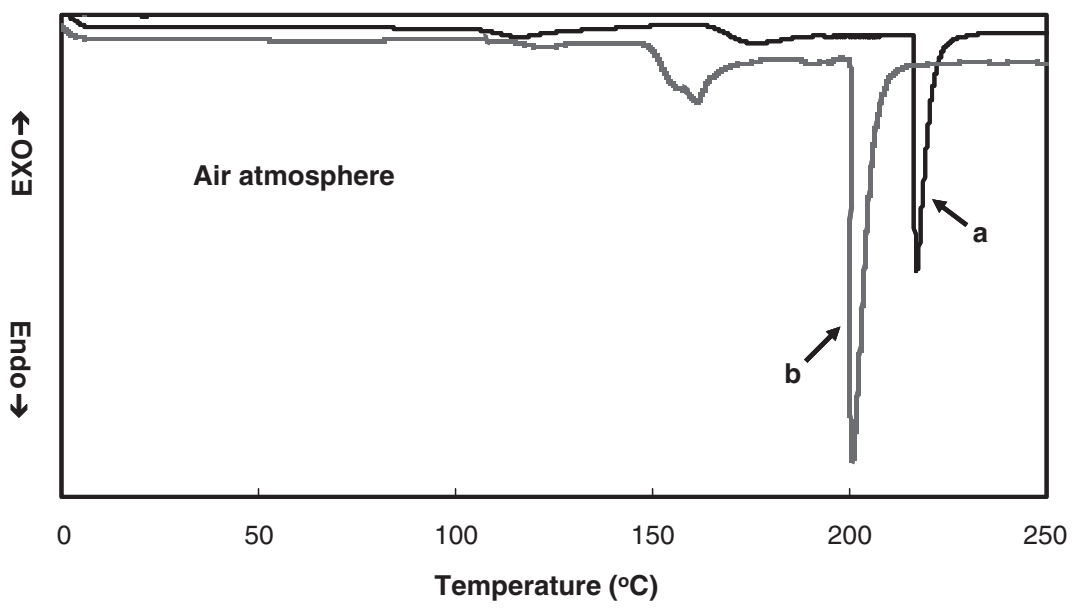

Figure 8. DSC curves of (a) Cell-(PMMA-b-PEMO) and (b) Cell-(PEMO-b-PMMA).

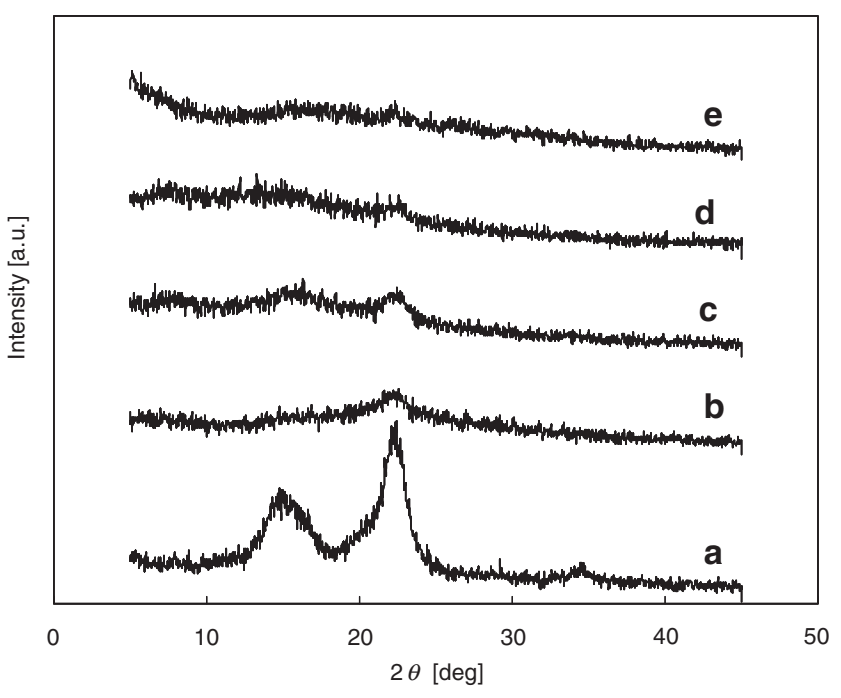

Figure 9. X-Ray diffraction diagram of (a) Cellulose, (b) Cell-ClAc, (c) CellPEMO, (d) Cell-(PEMO- $b$-PMMA), and (e) Cell-PEMO-PCL.

It indicated that the microcrystal structure of cellulose was almost damaged by the acylation reaction of cellulose. In addition, the existence of the relatively small peak at the diffraction angle of $2 \theta=22.1^{\circ}$ in Cell-ClAc pattern was considered that the hydroxyl groups in glucose units of cellulose were not substituted fully, thus the microcrystalline structure caused by these hydroxyl groups partly remained. Seeing the comparison of Cell-ClAc and Cell-PEMO patterns, in the Cell-PEMO pattern, the diffraction peak at $2 \theta=14.8^{\circ}$ became stronger than the peak of Cell-ClAc. It was presumed that through the ATRP of EMO, the PEMO chains were formed on the Cell-ClAc backbone from the halogen terminals of Cell$\mathrm{ClAc}$, hence, an amorphous structure was formed. The patterns of Cell-(PEMO- $b$-PMMA) and Cell-PEMO-PCL exhibited further smooth than Cell-PEMO and Cell-ClAc, respectively. It suggested that after the second ATRP of MMA initiated by Cell-PEMO, or the ROP of CL proceeded simultaneously with the ATRP of EMO both initiated by Cell-ClAc, the crystalline structure of cellulose almost disappeared.

\section{CONCLUSION}

In conclusion, Cell-ClAc was synthesized by the acylation reaction of cellulose in a homogeneous medium of a DMAc/ $\mathrm{LiCl}$ mixture. And pyridine was used as the acid scavenger in the acylation reaction. ATRPs of EMO and MMA were performed respectively by using Cell-ClAc as initiator. Further more, the second ATRP of EMO and MMA were conducted by using Cell-PMMA and Cell-PEMO as initiators, respectively. In order to obtain a better modification effect of Cellulose, the AGET ATRPs of EMO and MMA proceed simultaneously with the ROPs of CL and LLA in the same reaction system were carried out respectively. The obtained products were analyzed by FT-IR, TG-DTA, DSC, and WAXD. And all the measurements suggested the progression of the reactions.

Acknowledgment. We would like to express thanks to Ube Industries Ltd. and Murakami Shoji Co., Ltd. for supplying the 3-ethyl-3-methacryloyloxymethyloxetane (EMO) and the microcrystalline cellulose, respectively.

Received: June 11, 2008 Accepted: September 5, 2008 Published: October 16, 2008

\section{REFERENCES}

1. J. Lindqvist and E. Malmstrom, J. Appl. Polym. Sci., 100, 4155 (2006).

2. Y. Nishio, Kobunshi, 57, 434 (2008)

3. D. Shen, H. Yu, and Y. Huang, J. Polym. Sci., Part A: Polym. Chem., 43, 4099 (2005).

4. Y. Liu, L. Yang, Z. Shi, and J. Li, Polym. Int., 53, 1561 (2004).

5. V. Jain, H. Xiao, and Y. Ni, J. Appl. Polym. Sci., 105, 3195 (2007).

6. D. Peng, Y. Li, X. Zhang, G. Lu, C. Feng, and X. Huang, Acta Chim. Sinica, 65, 2144 (2007).

7. H. Liu and Y. Hsieh, J. Polym. Sci., Part B: Polym. Phys., 41, 953 (2003).

8. J. N. Kizhakkedathu, K. R. Kumar, D. Goodman, and D. E. Brooks, Polymer, 45, 7471 (2004).

9. S. G. Boyes, W. J. Brittain, X. W, and S. Z. D. Cheng, Macro- 
molecules, 35, 4960 (2002).

10. I. Ikeda, T. Higuchi, and Y. Maeda, Sen'I Gakkaishi, 58, 308 (2002).

11. Y. Teramoto and Y. Nishio, Cellulose Commun., 11, 115 (2004).

12. I. Ikeda, E. Yamaoka, and Y. Maeda, Sen'I Gakkaishi, 55, 279 (1999).

13. Y. Tsujii, K. Ohno, S. Yamamoto, A. Goto, and T. Fukuda, Adv. Polym. Sci., 197, 1 (2006).

14. K. Matyjaszewski and J. Xia, Chem. Rev., 101, 2921 (2001).

15. J. Wang and K. Matyjaszewski, J. Am. Chem. Soc., 117, 5614 (1995).

16. M. Kamigaito, T. Ando, and M. Sawamoto, Chem. Rev., 101, 3689 (2001).

17. M. Kato, M. Kamigaito, M. Sawamoto, and T. Higashimura, Macromolecules, 28, 1721 (1995).

18. F. Chang, T. Masaki, K. Kurachi, Y. Isobe, K. Onimura, and T. Oishi, Kobunshi Ronbunshu, 64, 254 (2007).

19. F. Chang, T. Masaki, K. Kurachi, Y. Isobe, K. Onimura, and T. Oishi, Kobunshi Ronbunshu, 64, 772 (2007).

20. I. Ikeda, K. Washino, and Y. Maeda, Sen'I Gakkaishi, 59, 110-114 (2003).

21. Y. Teramoto, M. Yoshioka, N. Shiraishi, and Y. Nishio, J. Appl. Polym. Sci., 84, 2621 (2002).

22. H. Shimizu, S. Sugihara, and I. Ikeda, Sen'i Gakkaishi, 64, 57 (2008).

23. A. I. Martin, M. Sanchez-Chaves, and F. Arranz, React. Funct. Polym., 39, 179 (1999).

24. J. Luo and Y. Sun, J. Appl. Polym. Sci., 100, 3288 (2006).

25. J. Xia and K. Matyjaszewski, Macromolecules, 30, 7697 (1997).
26. S. Monge, V. Darcos, and D. M. Haddleton, J. Polym. Sci., Part A: Polym. Chem., 42, 6299 (2004).

27. C. R. Becer, R. Hoogenboom, D. Fournier, and U. S. Schubert, Macromol. Rapid Commun., 28, 1161 (2007).

28. N. K. Singha, S. Rimmer, and B. Klumperman, Eur. Polym. J., 40, 159 (2004)

29. T. Morinaga, M. Ohkura, K. Ohno, Y. Tsujii, and T. Fukuda, Macromolecules, 40, 1159 (2007).

30. Z. Fu, Y. Shi, S. Jiao, and M. Huang, Acta Polym. Sin., 6, 692 (1999).

31. D. Wu, Y. Yang, X. Cheng, L. Liu, J. Tian, and H. Zhao, Macromolecules, 39, 7513 (2006).

32. H. Zhao, X. Kang, and L. Liu, Macromolecules, 38, 10619 (2005).

33. K. Min, H. Gao, and K. Matyjaszewski, J. Am. Chem. Soc., 127, 3825 (2005).

34. W. Jakubowski and K. Matyjaszewski, Macromolecules, 38, 4139 (2005).

35. B. Luan, Q. Yuan, and C. Pan, Macromol. Chem. Phys., 205, 2097 (2004).

36. A. Mayumi, T. Kitaoka, and H. Wariishi, J. Appl. Polym. Sci., 102, 4358 (2006).

37. Q. Zhou, L. Zhang, H. Okamura, M. Minoda, and T. Miyamoto, J. Polym. Sci., Part A: Polym. Chem., 39, 376 (2001).

38. K. M. Picker and S. W. Hoag, J. Pharm. Sci., 91, 342 (2002).

39. H. Maeda, M. Nakajima, T. Hagiwara, T. Sawaguchi, and S. Yano, J. Mater. Sci., 41, 5646 (2006).

40. M. Coskun and M. Temuz, Polym. Int., 54, 342 (2005). 